\title{
Avaliação Microbiológica e Aplicação de Boas Práticas de Fabricação de Salames Coloniais Produzidos no Município de Dois Vizinhos - PR
}

\author{
Marcela Tostes Frata (I), Lilian Kelly Pereira (I) \\ (I) UTFPR - Universidade Tecnológica Federal do Paraná (Estrada para Boa Esperança, Km 04 \\ CEP 85660-000 - Dois Vizinhos - PR )
}

\section{Resumo}

O consumo do salame colonial é um hábito comum da população da região sudoeste do Paraná. A produção desses alimentos geralmente ocorre em agroindústrias familiares de forma artesanal, sendo que os produtores rurais desconhecem as Boas Práticas de Fabricação (BPF), produzindo alimentos com qualidade microbiológica duvidosa, trazendo riscos à saúde do consumidor. A fim de promover a melhoria das condições de preparo dos mesmos, foram coletadas em duas etapas, oito amostras de salames e swab das mãos dos manipuladores e de utensílios em duas agroindústrias familiares localizadas no município de Dois Vizinhos, PR, as quais foram submetidas às seguintes análises microbiológicas: contagem total de aeróbios mesófilos, coliformes totais, coliformes termotolerantes, Staphylococcus aureus e pesquisa de Salmonella sp, nos laboratórios da Universidade Tecnológica Federal do Paraná, Câmpus Dois Vizinhos, de acordo com metodologia prevista pela legislação. Foi aplicado um check list resumido das condições de BPF dos locais. Após o diagnóstico da situação, foram passadas instruções das adequações que as agroindústrias deveriam adotar. Houve a presença de Salmonella sp. em uma das amostras, porém a mesma não foi encontrada nas mãos dos manipuladores e nos utensílios, denotando que a contaminação poderia estar na matériaprima. Em todas as amostras foi detectada contaminação por coliformes termotolerantes superior à permitida e houve a presença de coliformes totais em todos os salames, nas mãos dos manipuladores e nos utensílios

\footnotetext{
Referência:

Marcela Tostes Frata, Lilian Kelly Pereira. Avaliação Microbiológica e Aplicação de Boas Práticas de Fabricação de Salames Coloniais Produzidos no Município de Dois Vizinhos - Pr. In: Anais do 12을 Congresso Latinoamericano de Microbiologia e Higiene de Alimentos - MICROAL 2014 [= Blucher Food Science Proceedings, num.1, vol.1]. São Paulo: Editora Blucher, 2014. 
das duas agroindústrias. Na análise de Staphylococcus aureus dos salames os resultados foram satisfatórios, entretanto, este estava presente nos utensílios e nas mãos dos manipuladores. Com a aplicação do check list observou-se que as condições físicas dos estabelecimentos estão comprometidas, pois dos dezessete itens observados, apenas cinco eram cumpridos por ambas as agroindústrias e não houve nenhuma modificação após as sugestões de adequações realizadas, demonstrando falta de motivação e de recursos financeiros dos produtores. Pôde-se concluir que a produção de salames no município de Dois Vizinhos está ocorrendo em estabelecimentos com situação precária de higiene, comprometendo sua qualidade e segurança microbiológica. Sendo assim, necessita-se de melhor fiscalização e maior rigidez para que se cumpram as normas para produção desse alimento.

Palavras-Chave: agroindústria familiar, contagem microbiana, gestão de qualidade, segurança alimentar

\section{Agência de Fomento:}

